\title{
DOSE DEPENDENCY OF L-ARGININE IN NEONATAL MYOCARDIAL PROTECTION: THE NITRIC OXIDE PARADOX
}

Michael T. Kronon, MD

Bradley S. Allen, MD

Ari Halldorsson, MD

Shaikh Rahman, $\mathrm{PhD}$

Tingrong Wang, MD

Michel Ilbawi, MD
Objectives: Recent experimental studies have suggested that enriching cardioplegic solution with L-arginine improves myocardial protection by increasing nitric oxide production. Nitric oxide, however, also generates the toxic oxygen-derived free radical peroxynitrite; thus these beneficial effects may be dose dependent, especially in vulnerable (stressed) hearts. Methods: Fifteen neonatal piglets underwent 60 minutes of ventilator hypoxia (inspired oxygen fraction 8\%-10\%) followed by 20 minutes of normothermic ischemia on cardiopulmonary bypass (stress). They were then protected for 70 minutes with multiple doses of blood cardioplegic solution. In 5 (group 1), the cardioplegic solution contained no L-arginine, in 5 (group 2), it was enriched with a $4 \mathrm{mmol} / \mathrm{L}$ concentration of L-arginine, and in 5 (group 3), a $10 \mathrm{mmol} / \mathrm{L}$ concentration of L-arginine. Myocardial function was assessed by means of pressure volume loops and expressed as a percentage of control, and coronary vascular resistance and conjugated diene production were measured during infusions of cardioplegic solution. Results: Compared with the protection afforded by blood cardioplegic solution without L-arginine (group 1), the addition of a $4 \mathrm{mmol} / \mathrm{L}$ concentration of L-arginine (group 2) significantly improved myocardial protection, resulting in complete return of systolic function (end-systolic elastance $38 \%$ vs $100 \% ; P<.001$ vs $4 \mathrm{mmol} / \mathrm{L}$ L-arginine) and preload recruitable stroke work (40\% vs $100 \% ; P<.001$ vs 4 mmol/L L-arginine); minimal increase in diastolic stiffness $(239 \%$ vs $158 \% ; P<.001$ vs 4 mmol/L L-arginine); and lower coronary vascular resistance, conjugated diene production, and myeloperoxidase activity $(P<.001 \mathrm{vs} 4 \mathrm{mmol} / \mathrm{L}$ L-arginine in each case). Conversely, supplementing the cardioplegic solution with a $10 \mathrm{mmol} / \mathrm{L}$ dose of L-arginine (group 3 ) negated these beneficial effects, resulting in depressed systolic function (end-systolic elastance $41 \% \pm 2 \% ; P<.001$ vs $4 \mathrm{mmol} / \mathrm{L}$ L-arginine) and preload recruitable stroke work (40\% \pm $2 \% ; P<.001$ vs 4 mmol/L L-arginine); increased diastolic stiffness (246\% $\pm 7 \% ; P<.001$ vs 4 mmol/L L-arginine); and higher conjugated diene production, myeloperoxidase activity, and coronary vascular resistance $(P<.001$ vs $4 \mathrm{mmol} / \mathrm{L}$ L-arginine in each case). Conclusions: Enriching cardioplegic solution with a $4 \mathrm{mmol} / \mathrm{L}$ concentration of L-arginine significantly improves myocardial protection by reducing oxygen-derived free radical formation by white blood cells, thus preserving vascular and myocardial function. However, these beneficial effects are dose dependent because $10 \mathrm{mmol} / \mathrm{L}$ concentrations of $\mathrm{L}$-arginine increase oxygenderived free radical production, resulting in vascular and myocardial dysfunction. (J Thorac Cardiovasc Surg 1999;118:655-64)
From the Division of Cardiovascular Surgery, The Heart Institute for Children, Hope Children's Hospital, Oak Lawn, Ill.

M.T.K is supported in part by the Pillsbury Fellowship.

Received for publication July 1, 1998; revisions requested Sept 23, 1998; revisions received May 6, 1999; accepted for publication June 10, 1999.
Address for reprints: Bradley S. Allen, MD, The Heart Institute for Children, Hope Children's Hospital, 4440 West 95th St, Oak Lawn, IL 60453.

Copyright @ 1999 by Mosby, Inc.

$0022-5223 / 99 \$ 8.00+0 \quad \mathbf{1 2} / \mathbf{1} / \mathbf{1 0 0 7 4 5}$ 
$\mathrm{R}$ ecent studies have suggested that enriching cardioplegic solutions with the amino acid L-arginine may improve myocardial protection by increasing nitric oxide production. ${ }^{1-4}$ Nitric oxide induces vasodilatation, which improves cardioplegic distribution, and reduces endothelial cell adherence of activated white blood cells (WBCs), thus preventing a leukocyte-mediated injury. ${ }^{1-7}$ Because nitric oxide levels are depressed after ischemia, and hypoxia and ischemia both increase leukocyte adherence during reperfusion, L-arginine should be most effective in stressed (hypoxic or ischemic) hearts. ${ }^{1-3,5,6}$ However, stressed hearts are more vulnerable to injury with reperfusion because they are less able to tolerate a further insult. ${ }^{3,8-12}$ Increased production of nitric oxide could therefore be potentially harmful, since nitric oxide also generates the toxic oxygen-derived free radical peroxynitrite..$^{2,5,6,13,14}$ This may explain why other studies have demonstrated an increase in myocardial injury with L-arginine, which is prevented by inhibiting nitric oxide production. ${ }^{2,13-15}$ The beneficial effects of nitric oxide (L-arginine) may therefore be dose dependent, especially in vulnerable stressed hearts. This study uses hypoxic-ischemic (stressed) neonatal hearts to investigate (1) whether Larginine improves myocardial protection in neonates and (2) whether L-arginine (nitric oxide) has a specific dose response.

\section{Methods}

Twenty-five neonatal (5-18 days old) piglets $(3.5-5 \mathrm{~kg}$ ) were premedicated with ketamine $(40 \mathrm{mg} / \mathrm{kg})$ intramuscularly and anesthetized with phenobarbital $(30 \mathrm{mg} / \mathrm{kg})$ intraperitoneally, followed by $5 \mathrm{mg} / \mathrm{kg}$ intravenously each hour. The lungs were ventilated via a tracheotomy with a volume ventilator (Servo 900B, Siemens/Elema, Solna, Sweden). All animals received humane care in compliance with the "Principles of Laboratory Animal Care," formulated by the National Society for Medical Research, and the "Guide for the Care and Use of Laboratory Animals" prepared by the Institute of Laboratory Animal Resources, National Research Council, and published by the National Academy Press, revised 1996. The experimental preparation, including cannulation for cardiopulmonary bypass (CPB), the $\mathrm{CPB}$ prime, and blood sample procurement, is comparable with that previously described..$^{9,10}$

\section{Experimental protocols}

Hypoxic-ischemic injury. All piglets underwent 60 minutes of ventilator hypoxia by lowering the fraction of inspired oxygen to $8 \%$ to $10 \%$, producing an arterial $\mathrm{Po}_{2}$ of 25 to 35 $\mathrm{mm} \mathrm{Hg}$ and an oxygen saturation of $65 \%$ to $70 \%$. Before hypoxemia, piglets were given transfusions as necessary to increase their hematocrit value to greater than $35 \%$. This simulates the chronic adaptive change of erythrocytosis and increases oxygen-carrying capacity, thereby allowing ischemia to be avoided during hypoxia. ${ }^{9,10,16}$ At the end of 60 minutes, piglets were placed on $\mathrm{CPB}$ at an inspired oxygen fraction of $100 \%$ for 5 minutes to produce a reoxygenation injury. ${ }^{9,10,16-18}$ The aorta was then clamped for 20 minutes at $37^{\circ} \mathrm{C}$ to add a normothermic ischemic injury to the hypoxic stress. Ten piglets served as controls for the hypoxic-ischemic stress. Five underwent myocardial biopsy to determine the biochemical changes, and the other 5 had the aortic clamp removed and $\mathrm{CPB}$ continued for 60 minutes without further ischemia to determine the functional changes. The other 15 piglets underwent 70 minutes of cardioplegic arrest according to the protocol described below.

Administration of cardioplegic solution. Cardioplegic solutions (CAPS Service, Research Medical Inc, Salt Lake City, Utah) are shown in Tables I and II. After the hypoxicischemic insult, piglets underwent 70 minutes of cardioplegic arrest. The protocol consisted of 5 minutes of warm $\left(37^{\circ} \mathrm{C}\right)$ induction (Table I) followed by 4 minutes of cold multidose cardioplegia (Table II), a 2-minute cold multidose infusion every 20 minutes, and a 4-minute warm $\left(37^{\circ} \mathrm{C}\right)$ cardioplegic reperfusate ("hot shot") before aortic unclamping. Cardioplegic solution was always infused at a continuously measured aortic root pressure of 40 to $50 \mathrm{~mm} \mathrm{Hg}$. Immediately after cardioplegia was started, piglets were cooled to a systemic temperature of $26^{\circ} \mathrm{C}$, and warming to $37^{\circ} \mathrm{C}$ was begun 16 minutes before aortic unclamping. All piglets undergoing cardioplegic arrest were weaned from CPB with no inotropic support 30 minutes after aortic unclamping. Final functional and biochemical measurements were made 30 minutes after arterial blood gas, $\mathrm{Ca}^{2+}$, and $\mathrm{K}^{+}$levels were normalized.

Cardioplegia groups. The 15 piglets undergoing cardioplegic arrest were divided into 3 groups.

Unmodified blood cardioplegic solution (group 1). In 5 piglets, the blood cardioplegic solution was not supplemented with L-arginine.

Low-dose L-arginine (group 2). In 5 piglets, the blood cardioplegic solution was enriched with low-dose L-arginine (4 $\mathrm{mmol} / \mathrm{L})$.

High-dose L-arginine (group 3). In the final 5 piglets, the blood cardioplegic solution was enriched with high-dose Larginine $(10 \mathrm{mmol} / \mathrm{L})$.

Myocardial oxygen consumption. After cardioplegic arrest, blood was obtained at 1-minute intervals from the cardioplegia line and coronary sinus over the 5 minutes of warm cardioplegic induction (groups 1 to 3), and myocardial oxygen consumption was calculated as previously described. ${ }^{20}$ The cumulative 5-minute myocardial oxygen consumption was determined by the sum of the individual 1-minute values and expressed per $100 \mathrm{~g}$ of heart tissue, which was determined by weighing the left ventricle at the conclusion of the experiment.

Myocardial performance. Left ventricular (LV) pressure and conductance catheter signals were amplified and digitized to inscribe LV pressure volume loops after first correcting for parallel conductance (myocardial tissue and blood viscosity) with the use of hypertonic saline solution according to the method of Baan, Van Der Velde, and Steendijk. ${ }^{20}$ 
Table I. Warm blood cardioplegic solution

\begin{tabular}{lclc}
\hline Cardioplegia additive & $\begin{array}{c}\text { Volume added } \\
(\mathrm{mL})\end{array}$ & $\begin{array}{c}\text { Component } \\
\text { modified }\end{array}$ & $\begin{array}{c}\text { Concentration } \\
\text { delivered }^{*}\end{array}$ \\
\hline $\mathrm{KCl}(2 \mathrm{mEq} / \mathrm{mL})$ & 10 & $\mathrm{~K}^{+}$ & $8-10 \mathrm{mEq} / \mathrm{L}$ \\
$\mathrm{THAM}(0.3 \mathrm{~mol} / \mathrm{L})$ & 225 & $\mathrm{pH}$ & $\mathrm{pH} 7.5-7.7$ \\
$\mathrm{CPD}$ & 225 & $\mathrm{Ca}^{2+}$ & $0.2-0.3 \mathrm{mmol} / \mathrm{L}$ \\
Aspartate/glutamate & 250 & Substrate & $13 \mathrm{mmol} / \mathrm{L}$ each \\
$\mathrm{D}_{50} \mathrm{~W}$ & 40 & Glucose & $<400 \mathrm{mg} / \mathrm{dL}$ \\
$\mathrm{D}_{5} \mathrm{~W}$ & 200 & Osmolarity & $380-400 \mathrm{mOsm}$ \\
$\mathrm{L}_{-}$Arginine & 50 & Nitric oxide & $4 \mathrm{mmol} / \mathrm{L}(\mathrm{group} 2)$ \\
& & & $10 \mathrm{mmol} / \mathrm{L}(\mathrm{group} \mathrm{3})$
\end{tabular}

THAM, Tromethamine; $C P D$, citrate-phosphate-dextrose; $D 50 \mathrm{~W}, 50 \%$ dextrose in water; $D 5 \mathrm{~W}, 5 \%$ dextrose in water.

"When mixed in a $4: 1$ ratio with blood.

${ }^{\dagger} \mathrm{L}$-Arginine was mixed in $\mathrm{D}_{5} \mathrm{~W}(50 \mathrm{~mL})$. In group 2, $20 \mathrm{mmol}$ of $\mathrm{L}$-arginine was added to the $\mathrm{D}_{5} \mathrm{~W}$, and in group 3, $50 \mathrm{mmol}$.

Table II. Cold multidose blood cardioplegic solution

\begin{tabular}{|c|c|c|c|}
\hline Cardioplegia additive & $\begin{array}{l}\text { Volume added } \\
(m L)\end{array}$ & $\begin{array}{l}\text { Component } \\
\text { modified }\end{array}$ & $\begin{array}{c}\text { Concentration } \\
\text { delivered }^{*}\end{array}$ \\
\hline $\mathrm{KCl}(2 \mathrm{mEq} / \mathrm{mL})$ & 10 & $\mathrm{~K}^{+}$ & $8-10 \mathrm{mEq} / \mathrm{L}$ \\
\hline THAM $(0.3 \mathrm{~mol} / \mathrm{L})$ & 200 & $\mathrm{pH}$ & $\mathrm{pH} 7.6-7.8$ \\
\hline CPD & 50 & $\mathrm{Ca}^{2+}$ & $0.5-0.6 \mathrm{mmol} / \mathrm{L}$ \\
\hline $\mathrm{D}_{5} \mathrm{~W} 1 / 4 \mathrm{NS}$ & 550 & Osmolarity & 340-360 mOsm \\
\hline \multirow[t]{2}{*}{ L-Arginine ${ }^{\dagger}$} & 50 & Nitric oxide & 4 mmol/L (group 2) \\
\hline & & & $10 \mathrm{mmol} / \mathrm{L}$ (group 3) \\
\hline
\end{tabular}

THAM, Tromethamine; $C P D$, citrate-phosphate-dextrose; $D 5 \mathrm{~W}, 5 \%$ dextrose in water; $N S$, normal saline solution.

"When mixed in a 4:1 ratio with blood.

${ }^{\dagger} \mathrm{L}$-Arginine was mixed in $\mathrm{D}_{5} \mathrm{~W}(50 \mathrm{~mL})$. In group 2, $17 \mathrm{mmol}$ of $\mathrm{L}$-arginine was added to the $\mathrm{D}_{5} \mathrm{~W}$, and in group $3,43 \mathrm{mmol}$.

The conductance catheter affords a very accurate technique for measuring instantaneous changes in ventricular volume in the small heart. ${ }^{21} \mathrm{~A}$ series of pressure volume loops was generated by transient occlusion of the inferior vena cava during an 8-second period of apnea. Measurements were made before hypoxia (baseline) and 30 minutes after CPB was discontinued. The end-systolic and end-diastolic pressure volume relationships, as well as preload recruitable stroke work, were analyzed with the use of a computer graphics program (Spectrum, Bowman-Gray School of Medicine, WinstonSalem, NC) on a 486-33 MHz Dell personal computer (Dell Computer Corporation, Round Rock, Tex). LV systolic performance was determined from the descending slope of the end-systolic pressure volume relationship by means of linear regression analysis and designated as end-systolic elastance. End-diastolic compliance was determine from the exponential regression of the end-diastolic pressure volume relationship. Global myocardial performance was assessed by preload recruitable stroke work, which was calculated as the integral of LV transmural pressure and cavity volume over each cardiac cycle. Functional measurements are expressed as absolute measurements as well as percent recovery of baseline values, with each piglet acting as its own control. After final hemodynamic measurements, all piglets were placed back on CPB and their hearts arrested with cold $\left(4^{\circ} \mathrm{C}\right)$ blood cardioplegic solution. Transmural LV biopsy speci- mens were obtained. Endocardial and epicardial portions were separated, frozen quickly in liquid nitrogen, and stored for biochemical analysis. A separate sample was obtained to measure myocardial water.

Physiologic measurements. Coronary vascular resistance (CVR) was determined during each cardioplegic infusion by measuring coronary sinus pressure and cardioplegic flow once a constant infusion rate with an aortic root pressure between 40 and $50 \mathrm{~mm} \mathrm{Hg}$ was achieved. CVR was calculated as previously described as the change in pressure across the coronary vascular bed, divided by the cardioplegia flow rate, multiplied by 80 , and expressed as dynes $\cdot \mathrm{sec} \cdot \mathrm{cm}^{-5} .9,10$

\section{Biochemical analysis}

Adenosine pool. Myocardial samples were crushed in a liquid nitrogen-cooled mortar and pestle and lyophilized (Savant Speed Vac Systems, Farmingdale, NY). The adenosine pool was determined as described previously according to the method of Sarin and associates. ${ }^{9,10,22}$ ATP levels are expressed as micrograms per gram of dry tissue.

Myeloperoxidase activity. Quantitative myeloperoxidase activity was determined as described previously by means of the modified procedures of Okabayashi, ${ }^{23}$ Halldorsson, ${ }^{24}$ and their associates. Enzyme activity is expressed as the change in optical density units per minute per milligram of tissue protein $(\Delta \mathrm{OD} / \mathrm{min} / \mathrm{mg}$ protein).

Antioxidant reserve capacity. Myocardial antioxidant 
Table III. Left ventricular function

\begin{tabular}{|c|c|c|c|c|c|c|c|c|}
\hline \multirow[b]{2}{*}{ Group } & \multicolumn{3}{|c|}{ End-systolic elastance } & \multicolumn{2}{|c|}{ Diastolic compliance } & \multicolumn{3}{|c|}{ Preload recruitable stroke work } \\
\hline & $\begin{array}{c}\chi \\
\text { Intercept }\end{array}$ & Slope ${ }^{*}$ & $\begin{array}{c}\% \\
\text { Recovery }\end{array}$ & $\begin{array}{c}\beta \\
\text { Coefficient }\end{array}$ & $\begin{array}{c}\% \text { Control } \\
\text { stiffness }\end{array}$ & $\begin{array}{c}\chi \\
\text { Intercept }\end{array}$ & Slope $e^{\dagger}$ & $\begin{array}{c}\% \\
\text { Recovery }\end{array}$ \\
\hline \multicolumn{9}{|c|}{ Hypoxic-ischemic stress } \\
\hline Baseline & $6.4 \pm 0.2$ & $35 \pm 2$ & - & $0.04 \pm 0.02$ & - & $10.7 \pm 0.3$ & $67 \pm 3$ & - \\
\hline Postbypass & - & - & - & - & - & - & - & - \\
\hline \multicolumn{9}{|c|}{$\begin{array}{l}\text { Unmodified blood } \\
\text { cardioplegia (group 1) }\end{array}$} \\
\hline Baseline & $6.5 \pm 0.1$ & $34 \pm 2$ & - & $0.04 \pm 0.01$ & - & $10.6 \pm 0.3$ & $66 \pm 3$ & - \\
\hline Postbypass & $6.7 \pm 0.2$ & $14 \pm 2$ & $41 \% \pm 2 \%$ & $0.1 \pm 0.02$ & $267 \% \pm 7 \%$ & $10.5 \pm 0.1$ & $26 \pm 3$ & $39 \% \pm 2 \%$ \\
\hline \multicolumn{9}{|c|}{$\begin{array}{l}\text { L-Arginine: } 4 \mathrm{mmol} / \mathrm{L} \\
\text { (group 2) }\end{array}$} \\
\hline Baseline & $6.3 \pm 0.2$ & $36 \pm 1$ & - & $0.05 \pm 0.02$ & - & $10.8 \pm 0.1$ & $69 \pm 3$ & - \\
\hline Postbypass & $6.5 \pm 0.1$ & $36 \pm 2$ & $100 \% \pm 2 \%$ & $0.08 \pm 0.01$ & $160 \% \pm 4 \%$ & $10.7 \pm 0.3$ & $69 \pm 2$ & $100 \% \pm 2 \%$ \\
\hline \multicolumn{9}{|c|}{$\begin{array}{l}\text { L-Arginine: } 10 \mathrm{mmol} / \mathrm{L} \\
\text { (group 3) }\end{array}$} \\
\hline Baseline & $6.4 \pm 0.1$ & $35 \pm 2$ & - & $0.04 \pm 0.02$ & - & $10.7 \pm 02$ & $68 \pm 2$ & - \\
\hline Postbypass & $6.6 \pm 0.2$ & $15 \pm 1$ & $\begin{aligned} 42 \% & \pm 2 \% \\
\mathrm{~F} & =2341 \\
P & <.001\end{aligned}$ & $0.1 \pm 0.01$ & $\begin{aligned} 259 \% & \pm 6 \% \\
\mathrm{~F} & =209 \\
P & <.001\end{aligned}$ & $10.6 \pm 0.2$ & $28 \pm 3$ & $\begin{aligned} 41 \% & \pm 2 \% \\
\mathrm{~F} & =601 \\
P & <.001\end{aligned}$ \\
\hline
\end{tabular}

$\chi$ Intercepts expressed in $\mathrm{mL}$.

*End-systolic elastance slope expressed in $\mathrm{mm} \mathrm{Hg} / \mathrm{mL}$.

'Preload recruitable stroke work slope expressed as $\left[\int(\mathrm{mm} \mathrm{Hg} \cdot \mathrm{mL}) / \mathrm{mL}\right]$.

${ }_{\ddagger}^{\ddagger} P<.001$ versus groups 1 and 3 .

reserve capacity was assessed as previously described by determining the in vitro lipid peroxidation in cardiac tissue that was homogenized and incubated with t-butylhydroperoxide at a concentration of $4 \mathrm{mmol} / \mathrm{L} \cdot{ }^{16,25}$ Antioxidant reserve capacity is expressed as malondialdehyde production in nanomoles per gram of protein of heart tissue. The higher the production of malondialdehyde to the oxidant stress (t-butylhydroperoxide), the lower the tissue antioxidant reserve capacity, indicating depletion of antioxidants caused by exposure of the heart to oxygen-derived free radicals during reperfusion.

Production of conjugated dienes. Myocardial conjugated dienes were assessed according to the modified method of Corongiu and Banni. ${ }^{26}$ Blood was obtained from the cardioplegia line and coronary sinus 1 and 5 minutes after the start of warm cardioplegia induction. Whole blood samples were centrifuged at $1000 \mathrm{~g}$ and frozen at $-70^{\circ} \mathrm{C}$. Conjugated dienes are stable at $-20^{\circ} \mathrm{C}$. Two hundred microliters of plasma was then extracted with $7 \mathrm{~mL}$ of $2: 1$ chloroform and methanol ( vol/vol), mixed vigorously for a minute or two, and then centrifuged at $1800 \mathrm{rmp}$ for 10 minutes. The $5 \mathrm{~mL}$ of organic layer (Lower) was washed and mixed with $2 \mathrm{~mL}$ of 0.003 $\mathrm{MHCl}$. The mixture was centrifuged at $1800 \mathrm{rmp}$ for $10 \mathrm{~min}-$ utes. The organic layer was dried (near dryness) under N2 current with the Fisher sample concentrator model 190 (Fisher Scientific, Pittsburgh, Pa), and then the dried material was resuspended in $1 \mathrm{~mL}$ of hexane. After being mixed, the sample was read at $233 \mathrm{~nm}$, subtracting a hexane blank. The same suspension was also scanned between 200 and $325 \mathrm{~nm}$. The more sensitive second derivative (D2) was then measured at $237 \mathrm{~nm}(\mathrm{x}), 242 \mathrm{~nm}\left(\mathrm{x}^{\prime}\right), 246 \mathrm{~nm}(\mathrm{y}), 251 \mathrm{~nm}\left(\mathrm{y}^{\prime}\right)$, from the scan between 200 to $325 \mathrm{~nm}$. Using the second derivative formula, conjugated dienes $(\mathrm{CD})$ were calculated as $\mathrm{CD}=(\mathrm{x}$ $\left.-x^{\prime}\right)+\left(y-y^{\prime}\right)$. Conjugated diene production across the myocardium at 1 and 5 minutes was then calculated as follows:

$$
C D p(O D / m L / m i n)=[(C D c s-C D a) \times 5] \times C F R
$$

where $\mathrm{CDp}=$ conjugated diene production, $\mathrm{OD}=$ optical density, $\mathrm{CDa}=$ conjugated dienes in cardioplegic solution, CDcs = conjugated dienes in coronary sinus, and $\mathrm{CFR}=$ cardioplegia flow rate.

Production of conjugated dienes was expressed per $100 \mathrm{gm}$ heart tissue by weighing the left ventricle at the conclusion of the experiment.

Myocardial water. Ventricular samples were placed in preweighed vials and dried to a constant weight at a temperature of $85^{\circ} \mathrm{C}$. The percent myocardial water was calculated by means of the following formula:

$$
\% \text { Myocardial water }=\frac{(\text { Wet weight }- \text { Dry weight })}{\text { Wet weight } \times 100}
$$

Statistics. Data were analyzed with JMP V2.0 software (SAS Institute, Inc, Cary, NC) on a Macintosh IIVX computer (Apple Inc, Cupertino, Calif). The paired Student $t$ test and 1 -way analysis of variance were used for comparison of variables among experimental groups. If the analysis of variance revealed a significant interaction, pair-wise tests of individual group means were compared by means of multiple compar- 


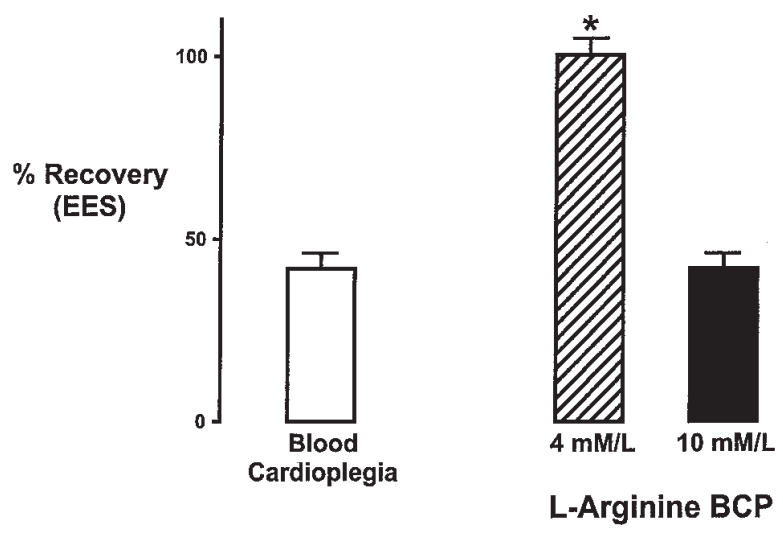

Fig 1. Recovery of LV systolic function as measured by endsystolic elastance (EES) and expressed as percentage of control (baseline). Note: Exposing the heart to hypoxia and ischemia produces such a severe stress that unmodified aspartate-glutamate blood cardioplegic solution is unable to fully resuscitate the heart. In contrast, cardioplegic solution enriched with a $4 \mathrm{mmol} / \mathrm{L}$ concentration of $\mathrm{L}$-arginine is able to fully resuscitate the hypoxic myocardium, resulting in complete return of systolic function. Conversely, these beneficial effects were negated if the L-arginine concentration was increased to $10 \mathrm{mmol} / \mathrm{L}$. ${ }^{*} P<.001$ (mean \pm standard error).

isons (Tukey's test) using a level of significance of $P<.05, P$ $<.01$, and $P<.001$. Group data are expressed as mean \pm standard error of the mean.

\section{Results}

There was no significant difference $(P>.2)$ between groups for baseline (pre-hypoxic) values of LV contractility $(35 \pm 2)$, diastolic compliance $(0.04 \pm 0.01)$, or preload recruitable stroke work $(68 \pm 3)$. All piglets tolerated 60 minutes of hypoxia with stable hemodynamics.

Hemodynamic and physiologic measurements. Results are depicted in Table III and Figs 1 to 4 . There was no significant change or difference $(P>.2)$ in the $\mathrm{X}$-axis intercept for end-systolic elastance or preload recruitable stoke work between prebypass (baseline) and postbypass values in any cardioplegia group. Therefore, the change in slope of end-systolic elastance and preload recruitable stroke work can be interpreted to express variability in the contractile state of the myocardium compared with baseline values. This allows the change in slope to be expressed as a percentage of baseline with each piglet to act as its own control. The combination of hypoxia and ischemia caused such a severe injury that CPB could not be discontinued in piglets not receiving cardioplegia (hypox-

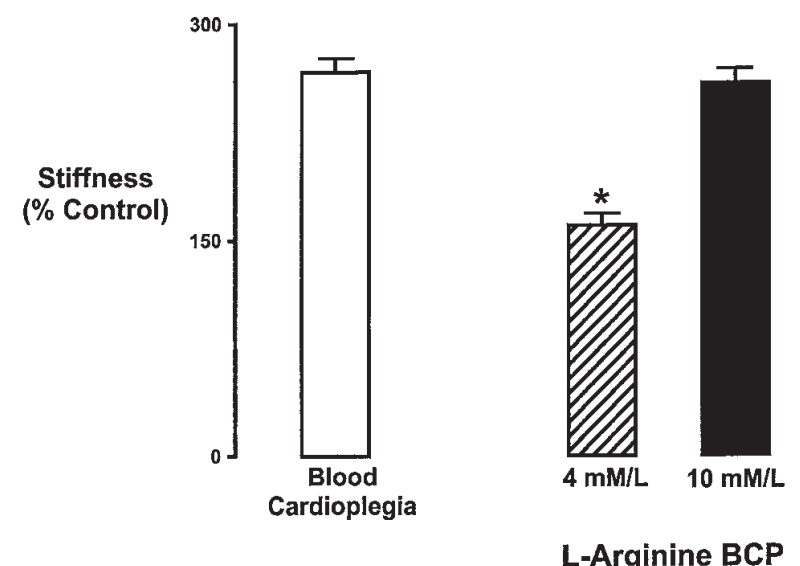

Fig 2. Postbypass LV diastolic compliance as measured by the end-diastolic pressure volume relationship and expressed as percentage of stiffness compared with control (baseline). Note: There is a marked increase in diastolic stiffness in hearts given unmodified blood cardioplegic solution. Conversely, enriching the cardioplegic solution with a 4 $\mathrm{mmol} / \mathrm{L}$ concentration of $\mathrm{L}$-arginine allowed for cellular repair of the hypoxic-ischemia injury, improving diastolic compliance. This beneficial effect was lost if the dose of Larginine was increased to $10 \mathrm{mmol} / \mathrm{L}$. ${ }^{*} P<.001$ (mean \pm standard error). $B C P$, Blood cardioplegic solution.

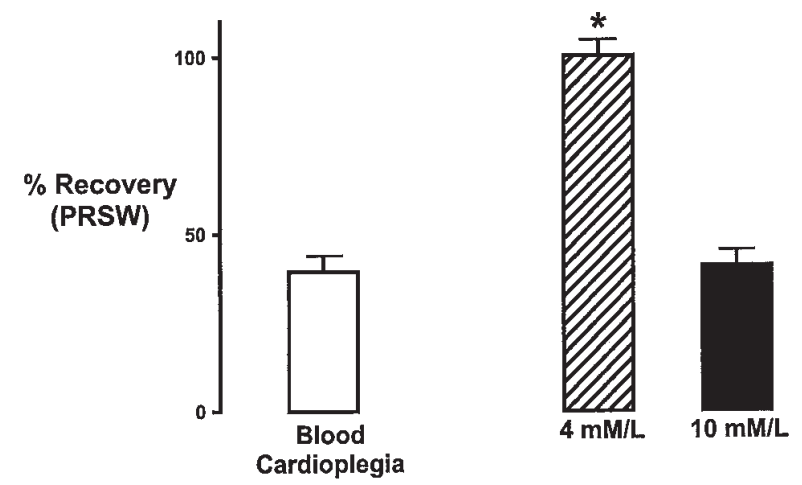

L-Arginine BCP

Fig 3. Recovery of overall myocardial function as measured by preload recruitable stroke work (PRSW) and expressed as percentage of control (baseline). $* P<.001$ (mean \pm standard error).

ic-ischemic controls), despite an additional 60 minutes of CPB support. Therefore no postbypass functional measurements could be obtained in these piglets. In contrast, blood cardioplegic solution without L-arginine (group 1) was able to partially resuscitate the hypoxic-ischemic myocardium, thereby allowing $\mathrm{CPB}$ to be discontinued. However, these piglets still had 


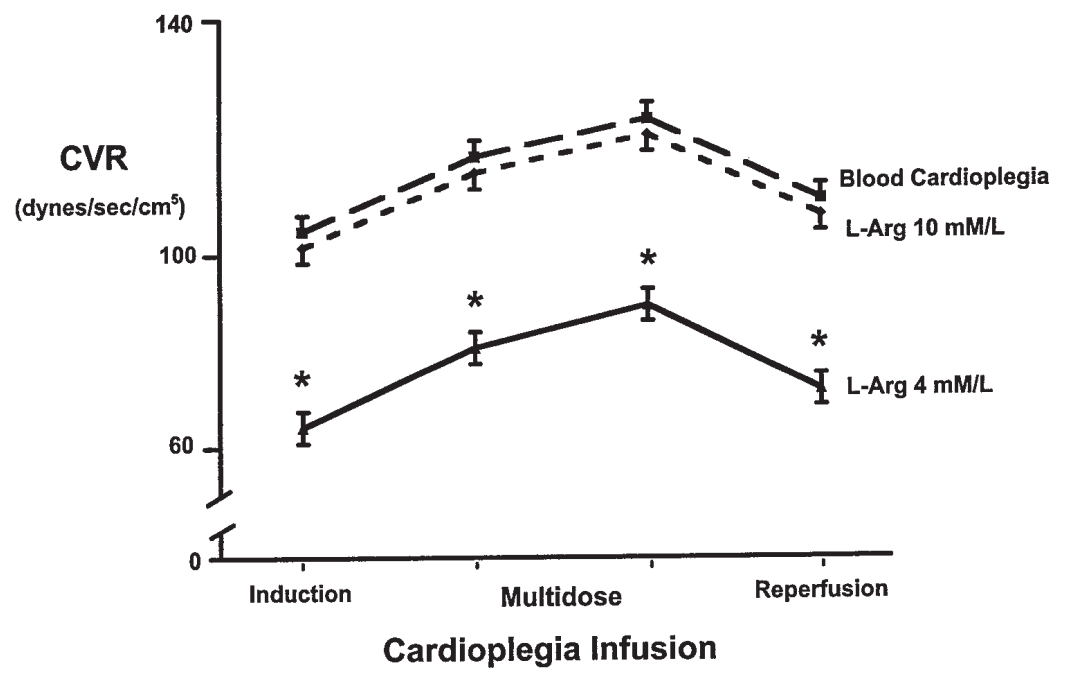

Fig 4. Coronary vascular resistance $(C V R)$ measured during cardioplegic infusion once the flow and cardioplegic pressures were stable. $* P<.001$ (mean \pm standard error).

depressed postbypass systolic contractility, markedly increased diastolic stiffness, and reduced preload recruitable stroke work. In contrast, cardioplegic solution supplemented with low-dose L-arginine $(4 \mathrm{mmol} / \mathrm{L}$, group 2) fully resuscitated and protected the severely stressed (hypoxic-ischemic) myocardium, resulting in complete return of systolic function and preload recruitable stroke work and minimal increase in diastolic stiffness. However, if the L-arginine concentration was increased to $10 \mathrm{mmol} / \mathrm{L}$ (group 3), these beneficial effects were negated, resulting in depressed systolic function, markedly increased diastolic stiffness, and reduced preload recruitable stroke work. CVR followed a similar trend, with low-dose L-arginine $(4 \mathrm{mmol} / \mathrm{L}$, group 2) resulting in lower CVR than either blood cardioplegia without L-arginine (group 1) or high-dose Larginine (10 mmol/L, group 3).

Biochemical studies. Results are summarized in Table IV. Compared with levels at the end of the hypoxic-ischemic stress, blood cardioplegic solution without L-arginine (group 1) improved the biochemical markers of injury. However, a significant oxygen-derived free radical reperfusion injury was documented by the high production of conjugated dienes and decreased tissue antioxidant reserve capacity. The myeloperoxidase activity was increased, and the adenosine triphosphate/diphosphate ratio (ATP/ADP ratio), which measures the ability of the mitochondria to phosphorylate ADP to ATP and is an indirect measurement of mitochondrial function, was decreased. Mitochondrial dysfunction (low ATP/ADP ratio) then prevented replenishment of ATP levels. In contrast, supplementing the cardioplegic solution with low-dose L-arginine (4 $\mathrm{mmol} / \mathrm{L}$, group 2) significantly decreased the production of oxygen-derived free radicals during reperfusion (low conjugated dienes and high antioxidant reserve capacity). This preserved mitochondrial function (normal ATP/ADP ratio), allowing replenishment of ATP levels, and explains the significantly higher myocardial oxygen consumption during warm cardioplegic induction. This reduction of injury correlated with a reduction in the myeloperoxidase activity. Conversely, highdose L-arginine $(10 \mathrm{mmol} / \mathrm{L}$, group 3$)$ increased the production of oxygen-derived free radicals (high conjugated dienes and low antioxidant reserve capacity), resulting in increased cellular injury, impaired metabolic recovery, and increased WBC accumulation (myeloperoxidase activity). The myocardial water (edema), which is an indirect measurement of cellular injury, was reduced with low-dose L-arginine (group 2), further supporting a decreased cellular injury in these hearts.

\section{Discussion}

The role of nitric oxide in myocardial protection remains controversial, because some reports demonstrate beneficial effects by enhancing production (Larginine), whereas others demonstrate a benefit to reducing production. ${ }^{2,3,5,6,13-15}$ These differences may be related to many factors, including the model used in the investigation, pathologic states of the myocardium, and the dosage of L-arginine. This study attempts to clarify the effects of L-arginine and nitric oxide production using an in vivo preparation that mimics the 
Table IV. Myocardial oxygen consumption and biochemical results

\begin{tabular}{|c|c|c|c|c|c|c|c|c|}
\hline \multirow[b]{2}{*}{ Group } & \multirow{2}{*}{$\begin{array}{c}\mathrm{MVO}_{2}{ }^{*} \\
(\mathrm{~mL} / 100 \mathrm{gm} / \\
5 \mathrm{~min})\end{array}$} & \multicolumn{2}{|c|}{$\begin{array}{c}\text { CD production }{ }^{*} \\
(\mathrm{OD} / \mathrm{mL} / 100 \mathrm{gm} / \mathrm{min}) \\
\end{array}$} & \multirow{2}{*}{$\begin{array}{c}A R C^{\dagger} \\
(M D A \text { nmol/ } \\
\text { g protein })\end{array}$} & \multirow{2}{*}{$\begin{array}{c}A T P \\
(\mu g / \\
g d r y w t)\end{array}$} & \multirow{2}{*}{$\begin{array}{l}\text { ATP } / A D P \\
\text { ratio }\end{array}$} & \multirow{2}{*}{$\begin{array}{c}\text { Myocardial } \\
\text { water } \\
(\%)\end{array}$} & \multirow{2}{*}{$\begin{array}{c}M P O \\
(\triangle O D / \mathrm{min} / \\
\text { mg protein })\end{array}$} \\
\hline & & $1 \mathrm{~min}$ & 5 min & & & & & \\
\hline Hypoxic-ischemic stress & - & - & - & $1441 \pm 24$ & $8.2 \pm 0.3$ & $1.1 \pm 0.2$ & $80.1 \pm 0.2$ & $2.4 \pm 0.2$ \\
\hline $\begin{array}{l}\text { Unmodified blood } \\
\text { cardioplegia (group 1) }\end{array}$ & $6.7 \pm 0.3$ & $72 \pm 2$ & $74 \pm 2$ & $1216 \pm 26^{\ddagger}$ & $10.8 \pm 0.6^{\ddagger}$ & $2.0 \pm 0.3^{\ddagger}$ & $80.7 \pm 0.2^{\ddagger}$ & $1.6 \pm 0.1^{\ddagger}$ \\
\hline $\begin{array}{l}\text { L-Arginine }(4 \mathrm{mmol} / \mathrm{L}) \\
\quad \text { (group } 2)\end{array}$ & $10.2 \pm 0.2^{\S}$ & $20 \pm 2^{\S}$ & $21 \pm 1^{\S}$ & $858 \pm 28^{\S}$ & $16.1 \pm 0.4^{\S}$ & $3.8 \pm 0.3^{\S}$ & $79.7 \pm 0.3^{\S}$ & $0.9 \pm 0.1^{\S}$ \\
\hline \multirow{3}{*}{$\begin{array}{l}\text { L-Arginine }(10 \mathrm{mmol} / \mathrm{L}) \\
\text { (group 3) }\end{array}$} & $6.9 \pm 0.3$ & $74 \pm 2$ & $75 \pm 2$ & $1234 \pm 17^{\ddagger}$ & $11.8 \pm 0.5^{\ddagger}$ & $1.9 \pm 0.2^{\ddagger}$ & $80.8 \pm 0.1^{\ddagger}$ & $1.8 \pm 0.2^{\ddagger}$ \\
\hline & $\mathrm{F}=105$ & $\mathrm{~F}=892$ & $F=49.5$ & $\mathrm{~F}=12.0$ & $\mathrm{~F}=43.7$ & $\mathrm{~F}=201$ & $\mathrm{~F}=467$ & $\mathrm{~F}=480$ \\
\hline & $\mathrm{P}<.001$ & $\mathrm{P}<.001$ & $\mathrm{P}<.001$ & $\mathrm{P}<.001$ & $\mathrm{P}<.001$ & $\mathrm{P}<.001$ & $\mathrm{P}<.001$ & $\mathrm{P}<.001$ \\
\hline
\end{tabular}

$M V O_{2}$, Myocardial oxygen consumption; $C D$, conjugated diene; $\mathrm{OD}$, optical density; $A R C$, antioxidant reserve capacity; $M D A$, malondialdehyde; $A T P$, adenosine triphosphate; $A D P$, adenosine diphosphate; $M P O$, myeloperoxidase.

"During cardioplegia induction (reperfusion).

MDA production at $4 \mathrm{mmol} / \mathrm{L} \mathrm{t}$-butylhydroperoxide.

${ }^{\ddagger} P<.001$ versus hypoxic-ischemic stress.

$\S P<.001$ versus all groups.

operative setting to avoid conflicting results that may not be clinically applicable. It also uses stressed hearts because they are the most difficult to protect, as well as the most vulnerable to further injury. The present study demonstrates the following: (1) The hypoxic-ischemic stress causes a severe injury; (2) blood cardioplegic solution without L-arginine is incapable of fully resuscitating or protecting the severely stressed (hypoxicischemic) neonatal heart; (3) supplementing the blood cardioplegic solution with low-dose L-arginine markedly improves myocardial protection by decreasing oxygen-derived free radical formation during reperfusion, preventing neutrophil accumulation, and preserving vascular function, resulting in complete return of myocardial contractility; and (4) increasing the dosage of L-arginine in blood cardioplegic solution nullifies these beneficial effects by increasing the formation of oxygen-derived free radicals during reperfusion, resulting in vascular dysfunction and depressed functional recovery.

In the presence of the enzyme nitric oxide synthase, the nonessential amino acid L-arginine combines with oxygen to produce nitric oxide and citrulline. $1,3,5,6,14$ Nitric oxide then reacts with the vascular endothelium, resulting in vasorelaxation, decreased platelet and WBC adherence, reduced chemotaxis of WBCs, and neutralization of superoxide radicals. ${ }^{1,2,5,6}$ In the presence of ischemia or hypoxia, reperfusion causes endothelial cell dysfunction with impaired release of nitric oxide. ${ }^{3,5,6,17,18,27}$ This may predispose the tissue to an exacerbated reperfusion injury caused by unscavenged oxygen-derived free radicals, vasoconstriction,

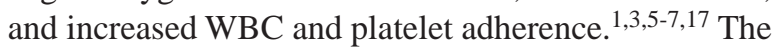

benefits of L-arginine supplementation of cardioplegic solutions is predicated on incorporating the nitric oxide precursor into endothelial cells with subsequent production and release of nitric oxide. Supplemental Larginine is indeed taken up by vascular endothelial cells, and the enhanced uptake results in increased production of nitric oxide. ${ }^{28}$ This explains why under certain conditions enriching cardioplegic solution with Larginine improves myocardial protection, reduces necrosis, and preserves endothelial cell function after cardioplegic arrest. ${ }^{1-4}$

Neonatal hearts in this study were subjected to both ischemia and hypoxia before cardioplegic arrest, whereas most of our previous studies have subjected the neonatal heart to either hypoxia or ischemia, but not both. ${ }^{8-10,16}$ We combined these 2 stresses because (1) blood cardioplegia without L-arginine is so effective that it results in complete return of function in neonatal hearts subjected to hypoxia alone $e^{9,10,30}$ and (2) this injury may more closely mimic the condition of the chronically cyanotic infant. This is because our model of acute hypoxia does not result in ischemia, whereas chronically hypoxic infants are subject to ischemia with ATP depletion during periods of acute stress. ${ }^{9-11,16,29-31}$ This probably explains why cyanotic infants often have depressed myocardial function after apparently successful surgical repair and provides an explanation of why we saw greater production of oxygen-derived free radicals in cyanotic infants than in animals subjected to acute hypoxia. ${ }^{11,12,16,25,31,32}$ However, even if our model does not completely mimic the clinical situation, it does subject the heart to a severe stress. This is important, because most neonatal hearts undergoing surgery are 
not "normal," but are subjected to hypoxia, ischemia, or a pressure volume overload. Furthermore, it is under these conditions that inhibitors of nitric oxide (ie, $N \omega$ nitro-L-arginine methyl ester) have been shown to be beneficial. ${ }^{2,13-15}$

The combination of hypoxia and ischemia caused such a severe stress that blood cardioplegic solution without L-arginine was unable to fully resuscitate the neonatal heart. Despite partial improvement, there was still a substantial increase in the production of oxygenderived free radicals. This damaged mitochondria (low ATP/ADP ratio), which explains the reduced oxygen uptake during cardioplegic induction, the lower postbypass ATP levels, and depressed functional recovery. In contrast, enriching the cardioplegic solution with lowdose L-arginine reduced the generation of oxygenderived free radicals during reperfusion. This prevented mitochondrial damage (normal ATP/ADP ratio), allowing replenishment of ATP, increased oxygen uptake during cardioplegic induction, and improved functional recovery. The myeloperoxidase activity, which is a measure of WBC sequestration, was also decreased in these hearts. This supports previous studies that have suggested that L-arginine acts primarily by preventing adherence of WBCs to the vascular endothelium. . $^{1,3,4}$ Once bound, WBCs then release proteases and oxygenderived free radicals, resulting in tissue damage. $.^{5-7} \mathrm{~L}-$ Arginine, however, may also scavenge oxygen-derived free radicals directly. The decrease in oxygen radical production could therefore be due to reduced WBC activity, neutralization of oxygen-derived free radicals directly, or both. Increasing the dose of L-arginine, however, completely negated these beneficial effects. Oxygen-derived free radical production was increased, resulting in mitochondrial damage and impaired postbypass functional recovery. Therefore, L-arginine (nitric oxide) has a paradoxic effect. In low concentrations, nitric oxide is beneficial by preventing WBC adherence, whereas if too much nitric oxide is produced, these beneficial effects are overwhelmed by the excess production of the oxygen-derived free radical peroxynitrite.

Another pathway by which nitric oxide may improve cardioplegic protection is through vasodilation. ${ }^{1-3,5,6}$ Perfusion defects can result from increased vascular resistance as a result of impaired production of nitric oxide or an increase in the vasoconstrictor endothelin. ${ }^{1,3}$ This can limit cardioplegic distribution. Lowdose L-arginine improved cardioplegic distribution by reducing CVR during infusions of cardioplegic solution. However, this lower resistance probably denotes preservation of normal vascular function, and not vasodilatation, since the coronary vasculature should be vasodilated after an ischemic stress. Conversely, the rise in CVR in the other cardioplegic groups (groups 1 and 3) suggests vascular dysfunction with vasoconstriction. High-dose L-arginine, however, should induce vasodilation and prevent a WBC injury because of increased levels of nitric oxide. The increased CVR with high-dose L-arginine therefore probably represents a vascular injury from overproduction of peroxynitrite. WBCs then migrate into the tissue as a result of the overwhelming reperfusion injury despite the decreased adherence caused by nitric oxide (L-arginine). We cannot prove that an increased CVR denotes a vascular injury, because specific tests of endothelial cell function were not performed after CPB. It is possible that the rise in CVR is due to increased cellular edema. We believe, however, that an increased CVR probably reflects a vascular injury because (1) the difference in myocardial water between groups is slight and (2) there is a direct correlation between oxygen-derived free radical production, CVR, and functional recovery.

Because this study suggests that L-arginine can be detrimental, we believe its use in patients may not be advisable for several reasons:

1. This and other studies reflect the optimal L-arginine dose in animals. Human beings, however, may have different levels of the enzyme nitric oxide synthase, and so the amount of nitric oxide produced may be different in patients exposed to a similar concentration of L-arginine.

2. There are 2 forms of the enzyme nitric oxide synthase that converts L-arginine to nitric oxide, inducible and noninducible. ${ }^{1-3,5-7,14}$ Several physiologic conditions (ie, angina) increase the concentration of inducible nitric oxide synthase. This may allow greater quantities of nitric oxide to be produced from a given concentration of L-arginine. ${ }^{5-7,14}$

3. The response to nitric oxide may be dependent on the pathologic state of the myocardium. Hearts subjected to hypoxia or ischemia already generate increased amounts of oxygen-derived free radicals with reperfusion and may therefore be more sensitive to the toxic oxygen radical peroxynitrite. ${ }^{8,16,17,27}$ This would explain why several studies that examined stressed (hypoxic or ischemic) hearts demonstrated a benefit with inhibition of nitric oxide synthesis during reperfusion or reoxygenation. ${ }^{2,13-15}$

4. Coronary artery disease can lead to maldistribution of cardioplegic solutions, with some regions of the myocardium receiving up to 10 times the flow per gram of muscle compared with other regions. ${ }^{8,33}$ Increased delivery of L-arginine-supplemented cardioplegic solu- 
tion to these segments might increase nitric oxide production.

5. The dose response must be known under both hypothermic and normothermic temperatures, because the conversion of L-arginine to nitric oxide is temperature dependent. It may therefore be undesirable to use a substance that has both positive and negative effects, and a dose response curve that is unknown in human beings and may change under various conditions. One cannot ignore, however, the potential beneficial effects of L-arginine. Until the aforementioned problems can be addressed, we believe L-arginine should be used cautiously and that alternative strategies or solutions that can provide a similar benefit without being potentially harmful should be investigated.

\section{REFERENCES}

1. Mizuno A, Baretti R, Buckberg GD, Young H, Vinten-Johansen J, $\mathrm{Ma} X$, et al. Endothelial stunning and myocyte recovery after reperfusion of jeopardized muscle: a role of L-arginine blood cardioplegia. J Thorac Cardiovasc Surg 1997;113:379-89.

2. Hiramatsu T, Forbess J, Miura T, Nomura F, Mayer JE Jr. Additive effects of L-arginine infusion and leukocyte depletion on recovery after hypothermic ischemia in neonatal lamb hearts. $\mathrm{J}$ Thorac Cardiovasc Surg 1995;110:172-9.

3. Sato H, Zhao Z, McGee DS, Williams MW, Hammon JW Jr, Vinten-Johansen J. Supplemental L-arginine during cardioplegic arrest and reperfusion avoids regional postischemic injury. $\mathrm{J}$ Thorac Cardiovasc Surg 1995;110:302-14.

4. Carrier M, Khalil A, Tourigny A, Solymoss B, Pelletier L. Effect of L-arginine on metabolic recovery of the ischemic myocardium. Ann Thorac Surg 1996;61:1651-7.

5. Boyle EM Jr, Pohlman TH, Cornejo CJ, Verrier ED. Ischemiareperfusion injury. Ann Thorac Surg 1997;64:S24-30.

6. Verrier ED, Boyle EM Jr. Endothelial cell injury in cardiovascular surgery: an overview. Ann Thorac Surg 1997;64:S2-8.

7. Boyle EM Jr, Pohlman TH, Johnson M, Verrier ED. Endothelial cell injury in cardiovascular surgery: the systemic inflammatory response. Ann Thorac Surg 1997;63:277-84.

8. Buckberg GD, Allen BS. Myocardial protection: management during adult cardiac operations. In: Baue AE, Geha AS, Hammond GL, Laks H, Naunheim KS, editors. Glenn's thoracic and cardiovascular surgery. 6th ed. Stamford (CT): Appleton \& Lange; 1995. p. 1653-87.

9. Bolling KS, Kronon M, Allen BS, Ramon S, Wang T, Hartz R, et al. Myocardial protection in normal and hypoxically stressed neonatal hearts: the superiority of hypocalcemic versus normocalcemic blood cardioplegia. J Thorac Cardiovasc Surg 1996; 112:1193-201.

10. Bolling KS, Kronon M, Allen BS, Wang T, Ramon S, Feinberg H. Myocardial protection in normal and hypoxically stressed neonatal hearts: the superiority of blood versus crystalloid cardioplegia. J Thorac Cardiovasc Surg 1997;113:994-1005.

11. Silverman N, Kohler J, Levitsky S, Pavel D, Fang R, Feinberg H. Chronic hypoxemia depresses global ventricular function and predisposes to depletion of high energy phosphates during cardioplegic arrest: implications for surgical repair of cyanotic congenital heart defects. Ann Thorac Surg 1984;37:304-8.
12. Hammon JW Jr, Graham TP Jr, Boucek RJ Jr, Parrish MD, Merrill WH, Bender HW Jr. Myocardial adenosine triphosphate content as a measure of metabolic and functional myocardial protection in children undergoing cardiac operation. Ann Thorac Surg 1987;44:467-70.

13. Morita K, Ihnken K, Buckberg GD, Sherman MP, Young HH. Studies of hypoxemic/reoxygenation injury: without aortic clamping. V. Role of the L-arginine-nitric oxide pathway. J Thorac Cardiovasc Surg 1995;110:1200-11.

14. Matheis G, Sherman P, Buckberg G, Haybron D, Young H, Ignarro L. Role of L-arginine-nitric oxide pathway in myocardial reoxygenation injury. Am J Physiol 1992;262:H616-20.

15. Schulz R, Wambolt R. Inhibition of nitric oxide synthesis protects the isolated working rabbit heart from ischemia-reperfusion injury. Cardiovasc Res 1995;30:432-9.

16. Bolling KS, Halldorsson A, Allen BS, Rahman S, Wang T, Kronon M, et al. Prevention of the hypoxic reoxygenation injury with the use of a leukocyte-depleting filter. J Thorac Cardiovasc Surg 1997;113:1081-90.

17. Buckberg GD. Studies of hypoxemic/rexoygenation injury: I. Linkage between cardiac function and oxidant damage. J Thorac Cardiovasc 1995;110:1164-70.

18. Ihnken K, Morita K, Buckberg GD, Sherman MP, Young HH. Studies of hypoxemic/reoxygenation injury: without aortic clamping. III. Comparison of the magnitude of damage by hypoxemia/reoxygenation versus ischemia/reperfusion. J Thorac Cardiovasc Surg 1995;110:1182-9.

19. Hanafy HM, Allen BS, Winkelmann JM, Ham JW, Osimani D, Hartz RS. Warm blood cardioplegic induction: an underused modality. Ann Thorac Surg 1994;58:1589-94.

20. Baan J, Van Der Velde E, Steendijk P. Ventricular pressure volume relations in vivo. Eur Heart J 1992;13(Suppl E):2-6.

21. Cassidy SC, Teitel DF. The conductance volume catheter technique for measurement of left ventricular volume in young piglets. Pediatr Res 1992;31:85-90.

22. Sarin M, Buinevicius Z, Levitsky S, Feinberg H. Isocratic highperformance liquid chromatographic analysis of myocardial creatine phosphate and adenine nucleotides. J Chromatogr 1991;563:129-33.

23. Okabayashi K, Aoe M, DeMeester SR, Cooper JD, Patterson AG. Pentoxifyllene reduces lung allograft reperfusion injury. Ann Thorac Surg 1994;58:50-6.

24. Halldorsson A, Kronon M, Allen BS, Bolling KS, Wang T, Rahman SK, et al. Controlled reperfusion after lung ischemia: implications for improved function after lung transplantation. J Thorac Cardiovasc Surg 1998;115:415-25.

25. Allen BS, Rahman SK, Ilbawi M, Feinberg H, Bolling KS, Kronon M. The detrimental effects of cardiopulmonary bypass in cyanotic infants: preventing the reoxygenation injury. Ann Thorac Surg 1997;64:1381-8.

26. Corongiu F, Banni S. Detection of conjugated dienes by second derivatives ultraviolet spectrophotometry. Methods Enzymol 1994;233:303-10.

27. Ihnken K, Morita K, Buckberg GD, Matheis G, Sherman MP, Allen BS, et al. Studies of hypoxemic/reoxygenation injury: without aortic clamping. II. Evidence for reoxygenation damage. J Thorac Cardiovasc Surg 1995;110:1171-81.

28. Palmer R, Ashton D, Moncada S. Vascular endothelial cells synthesize nitric oxide from L-arginine. Nature 1988;333:6646.

29. Boucek RJ Jr, Kasselberg AG, Boerth RC, Parrish MD, Graham 
TP Jr. Myocardial injury in infants with congenital heart disease: evaluation by creatine kinase MB isoenzyme analysis. Am J Cardiol 1982;50:129-35.

30. Graham TP Jr, Erath HG Jr, Buckspan GS, Fisher RD. Myocardial anaerobic metabolism during isoprenaline infusion in a cyanotic animal model: possible cause of myocardial dysfunction in cyanotic congenital heart disease. Cardiovasc Res 1979;13:401-6.

31. Del Nido PJ, Mickle DAG, Wilson GJ, Benson LN, Weisel RD, Coles JG, et al. Inadequate myocardial protection with cold car- dioplegic arrest during repair of tetralogy of Fallot. J Thorac Cardiovasc Surg 1988;95:223-9.

32. Rocchini AP, Keane JF, Castaneda AR, Nadas AS. Left ventricular function following attempted surgical repair of tetralogy of Fallot. Circulation 1978;57:798-802.

33. Guyton R, Gott J, Brown W, Craver J. Cold and warm myocardial protection techniques. In: Karp RB, Laks H, Wechsler AS, editors. Advances in cardiac surgery. St Louis: Mosby-Year Book; 1996. p. 1-30.

\section{THE THORACIC SURGERY FOUNDATION FOR RESEARCH AND EDUCATION}

\section{Kennedy School Sabbatical}

The Thoracic Surgery Foundation for Research and Education announces that applications for a year-long sabbatical to do graduate studies in health care policy at Harvard University's Kennedy School of Government are now available. Candidates will be accepted early on a rolling admission basis by the graduate school, and scholarships will be awarded by The Foundation's Education Committee. The Kennedy School will review completed applications for the program starting January 3, 2000, and is prepared to make decisions on applications within two weeks of their receipt. The Foundation will make a decision on an application for Alley-Sheridan Scholarship within two weeks of its receipt to The Foundation office. If an interested surgeon has applied to The Kennedy School very early in January, it is possible to have the admission and scholarship decisions completed by February 1. Please call Lainie Castle at The Foundation office for more information at 312-644-6610, extension 4798. 